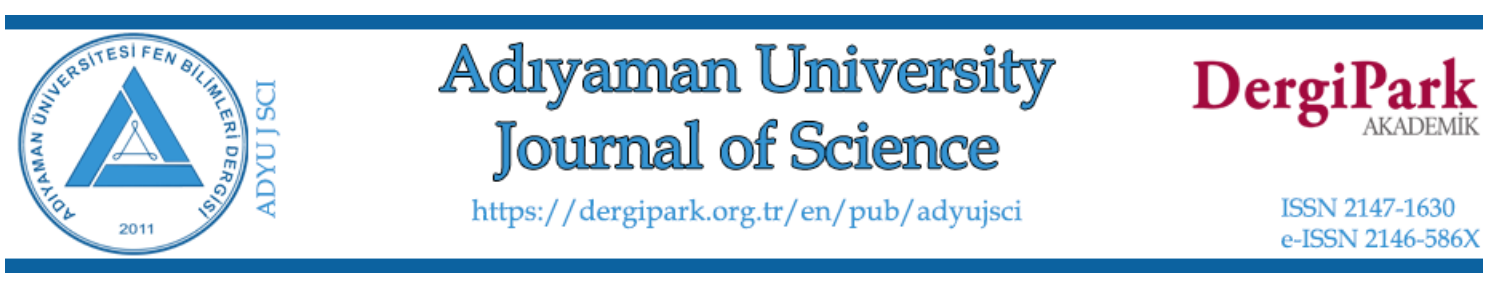

\title{
Evaluation of Radiation Attenuation Properties of Some Cancer Drugs
}

\author{
İlyas ÇAĞLAR ${ }^{1, *}$, Gülçin BİLGİCI CENGİZ² \\ ${ }^{1}$ Kafkas University, Kazım Karabekir Vocational School of Technical Sciences, Department of Electricity \\ and Energy, 36100 Kars, Türkiye \\ ilyas.caglar@kafkas.edu.tr, ORCID:0000-0002-6958-8469 \\ ${ }^{2}$ Kafkas University, Faculty of Arts and Sciences, Department of Physics, 36100 Kars, Türkiye \\ gulcincengiz@kafkas.edu.tr,ORCID:0000-0002-6164-3232
}

\begin{abstract}
The present study was conducted to estimate the radiation attenuation parameters of six different antineoplastic drugs used in the cure of cancer diseases. The effective atomic number and electron density of anastrozole, epirubicin, gemcitabine, ifosfamide, methotrexate and paclitaxel were computed theoretically in the energy region of $1 \mathrm{keV}$ to $100 \mathrm{GeV}$. The energy absorption buildup factors (EABF) and exposure buildup factors (EBF) for these chemotherapy drugs were also examined by applying Geometric Progression (GP) fitting method. The variation of $\mathrm{EABF}$ and $\mathrm{EBF}$ values with photon energy and penetration depth were presented graphically and discussed. The results obtained from this study pointed out that buildup factors rely on the chemical combination of the drugs, incident photon energy and penetration thickness. It was observed that ifosfamide had a significantly better radiation absorption effect compared to other drugs. The data obtained from this study are expected to be useful in the fields of radiation biology, radiation dosimetry and radiotherapy.
\end{abstract}

Keywords: Cancer drugs; Radiation; Effective atomic number; Effective electron density; Buildup factors.

Bazı Kanser İlaçlarının Radyasyon Soğurma Özelliklerinin Değerlendirilmesi 


\section{Öz}

$\mathrm{Bu}$ çalışma, kanser hastalıklarının tedavisinde kullanılan altı farklı antineoplastik ilacın radyasyon zayıflama parametrelerini değerlendirmek için gerçekleştirilmiştir. Anastrozol, epirubisin, gemsitabin, ifosfamid, metotreksat ve paklitakselin etkin atom numarası ve etkin elektron yoğunluğu $1 \mathrm{keV}$ ile $100 \mathrm{GeV}$ enerji bölgesinde teorik olarak hesaplandı. Bu kemoterapi ilaçları için enerji soğurma yığılma faktörleri (EABF) ve maruz kalma yığılma faktörleri (EBF) de GP fit yöntemi uygulanarak incelenmiştir. EABF ve EBF değerlerinin foton enerjisi ve nüfuz etme derinliği ile değişimi grafiksel olarak sunulmuş ve tartışılmıştır. Bu çalışmadan elde edilen sonuçlar, yığılma faktörlerinin ilaçların kimyasal kombinasyonuna, gelen foton enerjisine ve nüfuz etme kalınlığına bağlı olduğuna işaret etti. İfosfamidin diğer ilaçlara göre önemli ölçüde daha iyi radyasyon soğurma etkisine sahip olduğu gözlemlendi. Bu çalışmadan elde edilen verilerin radyasyon biyolojisi, radyasyon dozimetrisi ve radyoterapi alanlarında faydalı olması beklenmektedir.

Anahtar Kelimeler: Kanser ilaçlar1; Radyasyon; Etkin atom numarası; Etkin elektron yoğunluğu; Yı̆̆ılma faktörleri.

\section{Introduction}

Ionizing radiation (X, gamma rays, etc.) performs a major act in the diagnosis and cure of illness in medical applications such as diagnostic radiology, radiotherapy and like, as it has the ability to acquire images and destroy cells or tumours [1]. Radiotherapy technologies, which are being updated day by day with the use of high energy radiation in cancer treatments, are now being implemented as a priority option for many types of cancer. Today, $60-70 \%$ of cancer cases receive radiotherapy at least once in the process after the disease is diagnosed [2]. In some cases, simultaneously chemotherapy and radiotherapy are effectively applied in the treatment of some types of cancer, and this treatment is called chemoradiotherapy. In this way, by increasing the sensitivity of the cells to radiation with chemotherapy, radiation is provided to be more effective on the cells. When ionizing radiation passes through biological tissues, it can cause chemical alterations in tissues, leading to cell damage or cell and tissue death [3]. Therefore, evaluation of the interaction parameters of $\mathrm{X}$ or gamma rays with chemotherapy drugs may be beneficial for the estimation of absorbed radiation doses and radiation dose limits in chemoradiotherapy treatments.

The prior knowledge of radiation attenuation parameters such as mass attenuation coefficients $\left(\mu_{\mathrm{m}}\right)$, effective atomic number $\left(\mathrm{Z}_{\text {eff }}\right)$, effective electron density $\left(\mathrm{N}_{\mathrm{el}}\right)$ and buildup factors are critical in various practices such as medical physics, radiation physics, radiation 
dosimetry, radiotherapy, computerized tomography, and radiation biology. The most basic parameter among these parameters is the mass attenuation coefficient, which measures the probability of photon interaction (absorption or scattering) with the drug sample and this parameter and other parameters can be calculated using $\mu_{\mathrm{m}}$ [4]. Buildup factor, an important term in radiation dosimetry besides that shield design can be categorized as energy absorption buildup factor $(\mathrm{EABF})$ and exposure buildup factor $(\mathrm{EABF})$. It depends on the atomic number of the absorber medium [5]. EABF is defined as the amount of absorbed or deposited energy in the interacting material and the detector response function is as the absorption in the interacting medium. EBF is defined as the amount of exposure and the detector response function is as the absorption in air [2,6]. Various methods have been developed in the literature to work out the buildup factors that take into account various parameters such as photon energy, absorbing medium properties and distance [7-10]. The GP fitting method $[7,11]$ is the most widely used method to calculate buildup factors of various materials. Using the GP fitting method, many researchers have studied buildup factors of various materials such as concretes [12], alloys [13, 14], glasses [15, 16], polymers [17], building materials [18] human organs and tissues [19], teeth [20], bioactive compounds [21], amino acids [22], enzyme inhibitors [23], thermoluminescent dosimetric (TLD) materials [24], solvents [6] and like. In these studies, it was emphasized that GP method is a suitable method for calculating photon buildup factors for various materials.

Antineoplastic drugs used in the cure of cancer illness are drugs conceived to disturb or avoid cellular proliferation by inhibiting deoxyribonucleic acid (DNA) synthesis. Antineoplastic drugs are generally classified as alkylating agents, antimetabolites, antitumor antibiotics, hormone and hormone antagonists, alkaloids and other antineoplastic drugs [25]. Anastrozole $\left(\mathrm{C}_{17} \mathrm{H}_{19} \mathrm{~N}_{5}\right)$, epirubicin $\left(\mathrm{C}_{27} \mathrm{H}_{26} \mathrm{NO}_{11}\right)$, gemcitabine $\left(\mathrm{C}_{9} \mathrm{H}_{11} \mathrm{~F}_{2} \mathrm{~N}_{3} \mathrm{O}_{4}\right)$, ifosfamide $\left(\mathrm{C}_{7} \mathrm{H}_{15} \mathrm{Cl}_{2} \mathrm{~N}_{2} \mathrm{O}_{2} \mathrm{P}\right)$, methotrexate $\left(\mathrm{C}_{20} \mathrm{H}_{22} \mathrm{~N}_{8} \mathrm{O}_{5}\right)$ and paclitaxel $\left(\mathrm{C}_{47} \mathrm{H}_{51} \mathrm{NO}_{14}\right)$ are some of the commonly used antineoplastic drugs in chemotherapy. Anastrozole is an aromatase inhibitor utilized in the handling of second-level breast cancer and avoids the production of the hormone oestrogen, which triggers the formation of breast cancer. Epirubicin is an anthracycline antitumor antibiotic and is used alone or in combination with other chemotherapy drugs to cure certain diseases such as breast and ovarian cancer. Ifosfamide, an alkylating oxazophosphorine agent, is one of the chemotherapy drugs that avoid the reproduction of cancer cell DNA by averting its reproduction. Today, it is used in the treatment of lymphoma, soft tissue sarcoma and advanced breast, testicle, ovarian, stomach and lung cancers. Methotrexate is a type of antimetabolite agent that inhibits DNA replication or causes apoptosis by synthesizing incorrect codes and is extensively used in the cure of various types of cancer diseases such as head and neck cancers, ovarian, bladder, cervix, stomach, large intestine, testicle, breast, bone cancer, choriocarcinoma cancers and etc. 
Similar to methotrexate, Gemcitabine is a type of antimetabolite agent. It is a chemotherapy drug used in the treatment of pancreas, lung, bladder and breast cancers as well as other tumours such as ovarian cancer, mesothelioma and head and neck cancers. Paclitaxel is an antitumor agent active against a wide variety of cancers that are generally considered to be resistant to conventional chemotherapy. It is effective in the treatment of metastatic breast or ovarian cancer [25-31].

Radio protective effects of various drugs have been estimated by many researchers. Oto et al. computed gamma ray interaction parameters (i.e. $\mu_{\mathrm{m}}, \mathrm{Z}_{\mathrm{eff}}, \mathrm{N}_{\mathrm{el}}, \mathrm{EABF}$ and $\mathrm{EBF}$ ) of different drugs used in cholinergic medications using WinXCOM computer program [1]. Sayyed et al. calculated $Z_{\mathrm{eff}}, \mathrm{N}_{\mathrm{el}}, \mathrm{EABF}$ and EBF for Nonsteroidal anti-inflammatory drugs (NSAIDs) [32]. Kavaz et al. computed photon buildup factors of some chemotherapy drugs by using the GP fitting method in the energy region $0.015-15 \mathrm{MeV}$ up to penetration depths of 40 mean free paths (mfp) [33]. Akman and Kaçal calculated some essential radiation attenuation parameters such as $\mu_{\mathrm{m}}, \mathrm{Z}_{\mathrm{eff}}$ and $\mathrm{N}_{\mathrm{el}}$ of some drugs used in Chemotherapy with the help of the WinXCOM program [34]. Ekinci et al. investigated the EABF and EBF of some anti-inflammatory drugs by using the GP fitting method [35]. Yorgun and Kavaz determined $\mu_{\mathrm{m}}, \mathrm{Z}_{\mathrm{eff}}, \mathrm{N}_{\mathrm{el}}$ of some cancer drugs at 13.81, 17.7, 26.34 and $59.54 \mathrm{keV}$ photon energies. They also computed EABF and EBF of these cancer drugs in the energy region $0.015-15 \mathrm{MeV}$ up to penetration depths of $40 \mathrm{mfp}$ [2].

The aim of this research work is to estimate radiation interaction parameters of six different antineoplastic chemotherapy drugs commonly used for cancer treatment. There is almost no study in the literature on the radiation absorption parameters of these drugs. Therefore, it may be useful to investigate the radiation interaction parameters of these drugs for chemoradiation dose limits and dose calculations. For this purpose, $Z_{\text {eff }}$ and $\mathrm{N}_{\mathrm{el}}$ values of some chemotherapy drugs such as anastrozole, epirubicin, gemcitabine, ifosfamide, methotrexate and paclitaxel were computed in the energy range of $1 \mathrm{keV}-100 \mathrm{GeV}$. Additionally, the energy absorption and exposure buildup factors of these antineoplastic chemotherapy drugs were calculated by means of GP fitting method for the energy range $0.015-15 \mathrm{MeV}$ up to the penetration depth of $40 \mathrm{mfp}$.

\section{Materials and Methods}

\subsection{Computation of $Z_{\text {eff }}$ and $N_{e l}$}

The mass attenuation coefficients for investigated drug samples were computed by using mixture rule given in the following equation $[36,37]$ : 


$$
\mu_{m}=\frac{\mu}{\rho}=\sum_{i} w_{i}\left(\frac{\mu}{\rho}\right)_{i}
$$

where $\rho$ is the density, $w_{i}$ and $\left(\frac{\mu}{\rho}\right)_{i}$ are the weight fraction and mass attenuation coefficient for individual element in drugs, respectively. The theoretical $\mu_{\mathrm{m}}$ values for the investigated drugs were determined using WinXCOM software package [38]. For the drug samples, the effective atomic number were computed with the help of the following formula $[1,33]$ :

$$
Z_{e f f}=\frac{\sum_{i} f_{i} A_{i}\left(\frac{\mu}{\rho}\right)_{i}}{\sum_{j} f_{j} \frac{A_{j}}{Z_{j}}\left(\frac{\mu}{\rho}\right)_{j}}
$$

where $\mathrm{f}_{\mathrm{i}}, \mathrm{A}_{\mathrm{i}}, \mathrm{Z}_{\mathrm{i}}$ and $\left(\frac{\mu}{\rho}\right)_{i}$ are the molar fraction, atomic weight, atomic number and mass attenuation coefficient of relative element in the drug samples, respectively. In addition, the effective electron density, a parameter closely related to the effective atomic number, can be calculated by following equation $[33,35]$ :

$$
N_{e l}=N_{a} \frac{n Z_{\text {eff }}}{\sum_{i} n_{i} A_{i}}=N_{A} \frac{Z_{\text {eff }}}{\langle A\rangle}(\text { electrons } / g)
$$

where $\mathrm{N}_{\mathrm{A}}$ represents the Avogadro constant and $\langle\mathrm{A}\rangle$ indicates average atomic mass of the material.

\subsection{Computation of EABF and EBF}

The energy absorption and exposure buildup of chemotherapy drugs under the study were determined in three steps. In the first step, Compton partial mass attenuation coefficient $\left((\mu / \rho)_{\text {Compton }}\right)$ and the total mass attenuation coefficient $(\mu / \rho)_{\text {Total }}$ values were determined for different elements $(Z=4-30)$ and also for investigated drug samples using WinXCOM program. Then the interpolation formula given in Eqn. (4) was employed to compute the equivalent atomic number $\left(Z_{\text {eq }}\right)$ of chosen drug by matching the ratio $\mathrm{R}\left(\left(\mu_{\mathrm{m}}\right)_{\text {Compton }} /\left(\mu_{\mathrm{m}}\right)_{\text {Total }}\right)$ at a particular photon energy with the convenient ratio of the pure element at the same energy $[7,39]$;

$$
Z_{\text {eq }}=\frac{Z_{1}\left(\log R_{2}-\log R\right)+Z_{2}\left(\log R-\log R_{1}\right)}{\log R_{2}-\log R_{1}}
$$

where R signifies the ratio for chosen drug samples at particular energy which lies between $\mathrm{R}_{1}$ and $R_{2}$. $Z_{1}$ and $Z_{2}$ denote atomic numbers of the elements corresponding to the ratios $R_{1}$ and $R_{2}$, respectively. More details for the calculation procedure can be found in reference [38]. In the 
second step, in order to evaluate buildup factors the GP fitting coefficients for elements were acquired from the ANSI/ANS-6.4.3 database [40]. This database provides the GP fitting parameters for 23 elements ( $Z=4-92)$, water, air and concrete in the energy region of $0.015-15$ $\mathrm{MeV}$ up to $40 \mathrm{mfp}$ [39]. The obtained $\mathrm{Z}_{\text {eq }}$ values were used to determine geometric progression (GP) fitting coefficients $\left(\mathrm{a}, \mathrm{b}, \mathrm{c}, \mathrm{d}\right.$, and $\mathrm{X}_{\mathrm{k}}$ ) for the drug samples using the following relation [33, $39,41]$;

$$
P=\frac{P_{1}\left(\log Z_{2}-\log Z_{e q}\right)+P_{2}\left(\log Z_{e q}-\log Z_{1}\right)}{\log Z_{2}-\log Z_{1}}
$$

where $\mathrm{P}$ denotes GP fitting parameters of studied drug samples. $\mathrm{P}_{1}$ and $\mathrm{P}_{2}$ are the values of GP fitting coefficients corresponding to the $Z_{1}$ and $Z_{2}$ atomic numbers at a specific energy, respectively. In the last step, the computed GP fitting coefficients were used to generate the energy absorption and exposure build-up for selected antineoplastic drugs at some standard photon energies in the energy range $0.015-15 \mathrm{MeV}$ up to $40 \mathrm{mfp}$ penetration depths. This calculation was accomplished by using the following GP fitting formulas [7, 33, 39, 41];

$$
\begin{aligned}
& B(E, X)=1+\frac{b-1}{K-1}\left(K^{X}-1\right) \quad \text { for } K \neq 1 \\
& B(E . X)=1+(b-1) \quad \text { for } K=1 \\
& K(E, X)=\mathrm{cx}^{\mathrm{a}}+d \frac{\tanh \left(\frac{\mathrm{x}}{X_{k}}-2\right)-\tanh (-2)}{1-\tanh (-2)} \quad \text { for } \mathrm{x} \leq 40 \mathrm{mfp}
\end{aligned}
$$

where $\mathrm{E}, \mathrm{x}$ and $\mathrm{K}(\mathrm{E}, \mathrm{X})$ are the photon energy, penetration depth in mfp and dose multiplicative factor, respectively. $a, b, c, d$ and $X_{k}$ are the GP fitting parameters and $b$ is the buildup factor at one mfp.

\section{Results and Discussion}

The chemical formula and elemental composition of the studied antineoplastic chemotherapy drugs are presented in Table 1 . The $\mu_{\mathrm{m}}$ values of anastrazol, epirubicin, gemcitabine, ifosfamide, methotrexate and paclitaxel drugs were computed using WinXCOM software package [37]. From the computed $\mu_{\mathrm{m}}$ values $\mathrm{Z}_{\mathrm{eff}}$ and $\mathrm{N}_{\mathrm{el}}$ values of investigated drugs were worked out with the help of the Eqn. (2) and (3) in the energy range from $1 \mathrm{keV}$ to $100 \mathrm{GeV}$.

Table 1: Chemical formula and elemental composition of investigated drugs

\begin{tabular}{lllllllll}
\hline \multirow{2}{*}{ Drug } & Chemical Formula & \multicolumn{6}{c}{ Weight fraction of elements (\%) } \\
\cline { 2 - 8 } & $\mathrm{H}$ & $\mathrm{C}$ & $\mathrm{N}$ & $\mathrm{O}$ & $\mathrm{F}$ & $\mathrm{P}$ & $\mathrm{Cl}$ \\
\hline
\end{tabular}




\begin{tabular}{ccccccccc}
\hline Anastrozole & $\mathrm{C}_{17} \mathrm{H}_{19} \mathrm{~N}_{5}$ & 0.065 & 0.696 & 0.239 & - & - & - & - \\
Epirubicin & $\mathrm{C}_{27} \mathrm{H}_{26} \mathrm{NO}_{11}$ & 0.048 & 0.600 & 0.026 & 0.326 & - & - & - \\
Gemcitabine & $\mathrm{C}_{9} \mathrm{H}_{11} \mathrm{~F}_{2} \mathrm{~N}_{3} \mathrm{O}_{4}$ & 0.042 & 0.411 & 0.160 & 0.243 & 0.144 & - & - \\
Ifosfamide & $\mathrm{C}_{7} \mathrm{H}_{15} \mathrm{Cl}_{2} \mathrm{~N}_{2} \mathrm{O}_{2} \mathrm{P}$ & 0.058 & 0.322 & 0.107 & 0.123 & - & 0.119 & 0.272 \\
Methotrexate & $\mathrm{C}_{20} \mathrm{H}_{22} \mathrm{~N}_{8} \mathrm{O}_{5}$ & 0.049 & 0.529 & 0.247 & 0.176 & - & - & - \\
Paclitaxel & $\mathrm{C}_{47} \mathrm{H}_{51} \mathrm{NO}_{14}$ & 0.060 & 0.661 & 0.016 & 0.262 & - & - & - \\
\hline
\end{tabular}

Figure 1 and 2 show the variation of the computed $Z_{\text {eff }}$ and $N_{\text {el }}$ values with photon energy for the investigated antineoplastic chemotherapy drugs. $Z_{\mathrm{eff}}$ and $\mathrm{N}_{\mathrm{el}}$ values of ifosfamide have a peak at $1.892 \mathrm{keV}$ photon energy, which correspond to the $\mathrm{K}$ absorption edge of chlorine. The computed $Z_{\text {eff }}$ values ranged from 3.68-6.30 for Anastrozole, 4.35-6.98 for epirubicin, 4.69-7.47 for gemcitabine, 4.70-12.35 for ifosfamide, 4.32-6.81 for methotrexate and 4.00-6.83 for paclitaxel, respectively. The $\mathrm{N}_{\mathrm{el}}$ values also ranged from $3.10 \times 10^{23}-4.26 \times 10^{23}$ electrons $/ \mathrm{g}$ for Anastrozole, $3.31 \times 10^{23}-4.11 \times 10^{23}$ electrons/g for epirubicin, $3.30 \times 10^{23}-4.05 \times 10^{23}$ electrons $/ \mathrm{g}$ for gemcitabine, $3.15 \times 10^{23}-8.26 \times 10^{23}$ electrons $/ g$ for ifosfamide, $3.30 \times 10^{23}-4.09 \times 10^{23}$ electrons $/ \mathrm{g}$ for methotrexate and $3.35 \times 10^{23}-4.28 \times 10^{23}$ electrons/g for paclitaxel, respectively. The highest $Z_{\text {eff }}$ and $\mathrm{N}_{\mathrm{el}}$ values of the studied drugs were observed in the low energy region $(\mathrm{E}<0.1 \mathrm{MeV})$ where photoelectric absorption which is cross section proportional to the $\mathrm{Z}^{4-5}$ and $\mathrm{E}^{-3.5}$ is the dominant interaction mechanism [23].

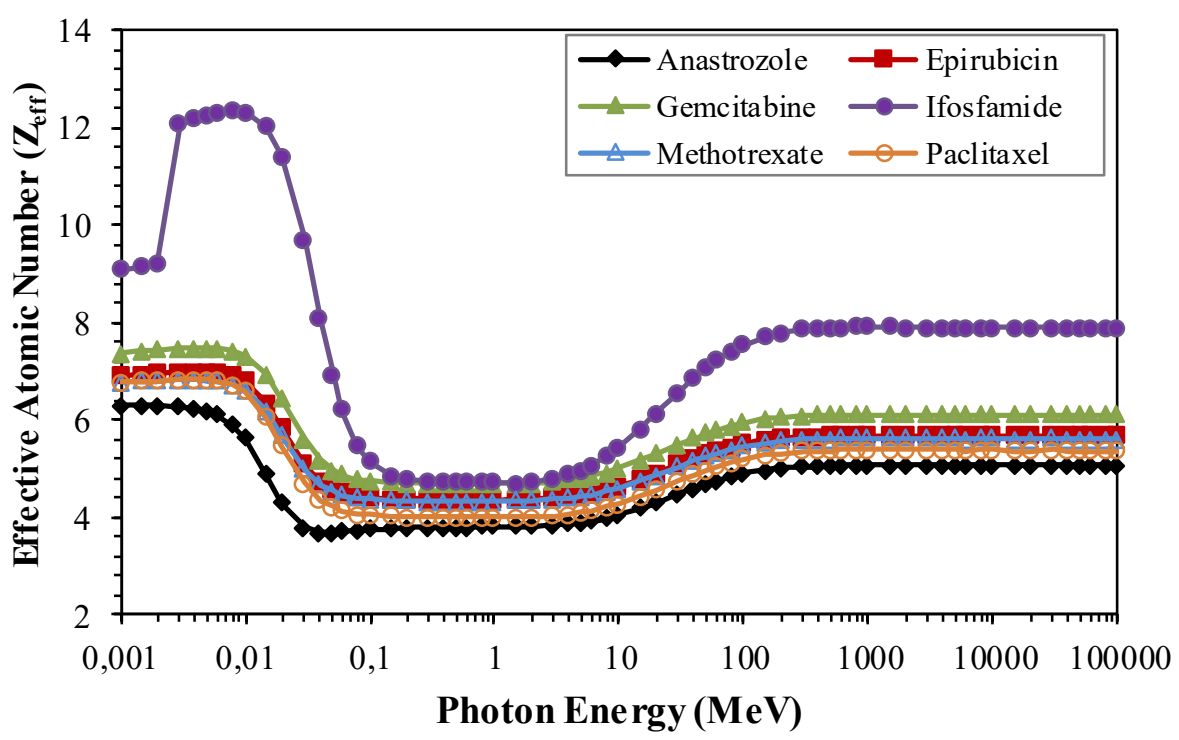

Figure 1: Zeff values of investigated chemotherapy drugs versus photon energy

As seen from Figs. 1 and 2, the lowest $Z_{\text {eff }}$ and $N_{\text {el }}$ values of the studied drugs were determined in the intermediate energies $(0.1 \mathrm{MeV}<\mathrm{E} 10 \mathrm{MeV})$. It was seen that in this energy region where Compton scattering is the most important interaction process, $\mathrm{Z}_{\mathrm{eff}}$ and $\mathrm{N}_{\mathrm{el}}$ values are almost independent to photon energy. This may be due to the weak dependence of the Compton scattering cross section to atomic number and photon energy (i.e. proportional to $\mathrm{Z}$ and $\mathrm{E}^{-1}$ ) [37]. 
At energies greater than $10 \mathrm{MeV}, Z_{\text {eff }}$ and $\mathrm{N}_{\mathrm{el}}$ values increase slowly with increasing photon energy and are almost constant at further energies. This change can be clarified by actually that pair production is the dominant interaction process at high energies. Because the pair productions cross section is directly proportional to $\mathrm{E}$ and $\mathrm{Z}^{2}$ [13]. This observed trend in $\mathrm{Z}_{\mathrm{eff}}$ and $\mathrm{N}_{\mathrm{el}}$ values is consistent with the results of the study reported by Oto et al. [1] who investigated radiation interaction parameters of some cholinergic drugs. As shown in Figs. 1 and 2, ifosfamide has considerably higher $Z_{\text {eff }}$ and $N_{\text {el }}$ values than other studied drugs in the low and high energy regions. In the intermediate energy region, the $Z_{\text {eff }}$ values of ifosfamide are slightly larger than those of the other drugs, while the $\mathrm{N}_{\mathrm{el}}$ values are approximately the same. The reason for this apparent difference in the $Z_{\text {eff }}$ and $N_{\mathrm{el}}$ values of ifosfamide may be that ifosfamide contains phosphate $(Z=15$, weight fraction $=0.119)$ and chlorine $(Z=17$, weight fraction $=0.272)$, unlike other drugs.

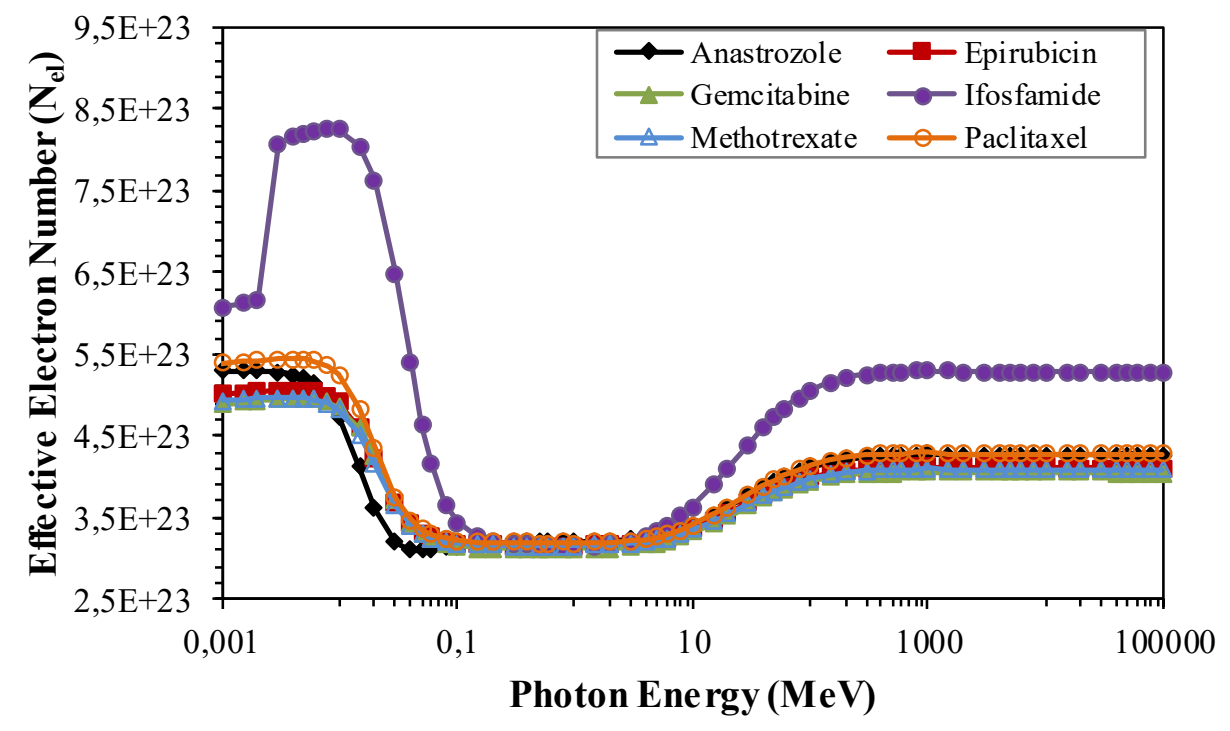

Figure 2: Nel values of investigated chemotherapy drugs versus photon energy

The $Z_{\text {eq }}$ values calculated using the interpolation formula given in Eqn. (4) in the 0.015-15 $\mathrm{MeV}$ energy range for the examined drugs are given in Table 2. It is obviously sighted from Table 2 that ifosfamide has the highest $Z_{\text {eq }}$ values among the examined antineoplastic drugs, while anastrozole has the lowest $Z_{\mathrm{eq}}$ values. The high $Z_{\mathrm{eq}}$ values of ifosfamide are due to the presence of phosphate $(Z=15$, weight fraction $=0.119)$ and chlorine $(Z=17$, weight fraction $=0.272)$ in the chemical structure of ifosfamide, unlike other drugs. Similarly, the reason why anastrozole has low $Z_{\text {eq }}$ values is due to the lack of oxygen, fluorine, phosphate and chlorine in the chemical structure of anastrozole. The GP fitting coefficients of the EABF and EBF for investigated radioprotectors are listed in Table 3-8 at the energy region of $0.015-15 \mathrm{MeV}$. 
Table 2: $Z_{\mathrm{eq}}$ values of investigated drugs at the energy region of $0.015-15 \mathrm{MeV}$

\begin{tabular}{ccccccc}
\hline Energy $(\mathrm{MeV})$ & Anastrozole & Epirubicin & Gemcitabine & Ifosfamide & Methotrexate & Paclitaxel \\
\hline 0.015 & 6.009 & 6.639 & 7.094 & 11.85 & 6.514 & 6.446 \\
0.02 & 6.014 & 6.636 & 7.099 & 11.97 & 6.509 & 6.443 \\
0.03 & 6.008 & 6.618 & 7.097 & 12.09 & 6.489 & 6.422 \\
0.04 & 5.989 & 6.598 & 7.086 & 12.13 & 6.468 & 6.399 \\
0.05 & 5.970 & 6.578 & 7.072 & 12.14 & 6.451 & 6.378 \\
0.06 & 5.951 & 6.562 & 7.059 & 12.13 & 6.436 & 6.360 \\
0.08 & 5.922 & 6.535 & 7.036 & 12.08 & 6.413 & 6.331 \\
0.1 & 5.901 & 6.515 & 7.017 & 12.00 & 6.396 & 6.309 \\
0.15 & 5.867 & 6.483 & 6.980 & 11.79 & 6.368 & 6.274 \\
0.2 & 5.850 & 6.463 & 6.954 & 11.62 & 6.352 & 6.253 \\
0.3 & 5.831 & 6.444 & 6.929 & 11.39 & 6.335 & 6.232 \\
0.4 & 5.823 & 6.435 & 6.917 & 11.26 & 6.327 & 6.222 \\
0.5 & 5.819 & 6.429 & 6.910 & 11.18 & 6.323 & 6.217 \\
0.6 & 5.816 & 6.427 & 6.906 & 11.14 & 6.321 & 6.214 \\
0.8 & 5.813 & 6.424 & 6.903 & 11.09 & 6.319 & 6.211 \\
1 & 5.813 & 6.423 & 6.902 & 11.08 & 6.318 & 6.210 \\
1.5 & 5.673 & 6.262 & 6.701 & 10.28 & 6.177 & 6.032 \\
2 & 5.630 & 6.206 & 6.637 & 9.77 & 6.126 & 5.968 \\
3 & 5.620 & 6.193 & 6.623 & 9.60 & 6.114 & 5.953 \\
4 & 5.617 & 6.190 & 6.620 & 9.56 & 6.111 & 5.949 \\
5 & 5.617 & 6.189 & 6.620 & 9.53 & 6.110 & 5.948 \\
6 & 5.617 & 6.188 & 6.618 & 9.53 & 6.110 & 5.947 \\
8 & 5.616 & 6.186 & 6.617 & 9.51 & 6.108 & 5.944 \\
10 & 5.617 & 6.184 & 6.617 & 9.51 & 6.106 & 5.942 \\
15 & 5.618 & 6.184 & 6.614 & 9.50 & 6.107 & 5.942 \\
\hline
\end{tabular}

Table 3: GP fitting parameters for anastrozole in the energy range $0.015-15 \mathrm{MeV}$

\begin{tabular}{|c|c|c|c|c|c|c|c|c|c|c|}
\hline \multirow{2}{*}{ Energy (MeV) } & \multicolumn{5}{|c|}{ EABF } & \multicolumn{5}{|c|}{ EBF } \\
\hline & b & c & $\mathbf{a}$ & $\mathbf{X k}$ & d & b & c & $\mathbf{a}$ & Xk & d \\
\hline 0.015 & 1.397 & 0.526 & 0.153 & 14.421 & -0.077 & 1.385 & 0.538 & 0.146 & 14.310 & -0.072 \\
\hline 0.02 & 1.895 & 0.737 & 0.077 & 16.436 & -0.037 & 1.872 & 0.730 & 0.080 & 16.546 & -0.040 \\
\hline 0.03 & 3,716 & 1.150 & -0.026 & 12.601 & 0.008 & 3.503 & 1.150 & -0.026 & 12.846 & 0.008 \\
\hline 0.04 & 5.073 & 1.740 & -0.128 & 14.102 & 0.056 & 5.276 & 1.750 & -0.130 & 13.917 & 0.064 \\
\hline 0.05 & 5.598 & 2.078 & -0.165 & 14.488 & 0.070 & 6.749 & 2.123 & -0.171 & 14.344 & 0.074 \\
\hline 0.06 & 5.420 & 2.304 & -0.187 & 14.668 & 0.079 & 7.270 & 2.408 & -0.200 & 14.522 & 0.089 \\
\hline 0.08 & 4.841 & 2.510 & -0.206 & 14.823 & 0.083 & 6.888 & 2.725 & -0.230 & 14.456 & 0.101 \\
\hline 0.1 & 4.280 & 2.569 & -0.210 & 14.926 & 0.083 & 6.107 & 2.836 & -0.239 & 14.368 & 0.104 \\
\hline 0.15 & 3.538 & 2.484 & -0.203 & 15.230 & 0.076 & 4.573 & 2.892 & -0.247 & 14.292 & 0.107 \\
\hline 0.2 & 3.184 & 2.360 & -0.194 & 15.211 & 0.073 & 3.775 & 2.771 & -0.239 & 14.949 & 0.108 \\
\hline 0.3 & 2.785 & 2.142 & -0.176 & 14.990 & 0.070 & 3.148 & 2.494 & -0.219 & 14.343 & 0.099 \\
\hline 0.4 & 2.613 & 1.942 & -0.155 & 14.758 & 0.063 & 3.027 & 2.268 & -0.201 & 13.324 & 0.085 \\
\hline 0.5 & 2.452 & 1.811 & -0.140 & 15.794 & 0.062 & 2.661 & 2.072 & -0.180 & 13.936 & 0.084 \\
\hline 0.6 & 2.392 & 1.673 & -0.121 & 14.937 & 0.047 & 2.544 & 1.904 & -0.159 & 13.615 & 0.068 \\
\hline 0.8 & 2.196 & 1.567 & -0.110 & 14.100 & 0.047 & 2.320 & 1.726 & -0.139 & 13.727 & 0.068 \\
\hline 1 & 2.087 & 1.463 & -0.094 & 14.158 & 0.041 & 2.203 & 1.567 & -0.114 & 13.737 & 0.057 \\
\hline 1.5 & 1.939 & 1.277 & -0.061 & 14.308 & 0.027 & 2.031 & 1.330 & -0.073 & 13.718 & 0.037 \\
\hline 2 & 1.840 & 1.173 & -0.039 & 14.390 & 0.016 & 1.918 & 1.199 & -0.046 & 14.147 & 0.023 \\
\hline 3 & 1.715 & 1.051 & -0.012 & 13.942 & 0.004 & 1.764 & 1.062 & -0.015 & 12.253 & 0.008 \\
\hline 4 & 1.627 & 0.989 & 0.003 & 13.594 & -0.003 & 1.664 & 0.983 & 0.005 & 22.560 & -0.007 \\
\hline 5 & 1.567 & 0.944 & 0.015 & 14.609 & -0.008 & 1.584 & 0.937 & 0.017 & 14.663 & -0.011 \\
\hline 6 & 1.521 & 0.901 & 0.029 & 12.647 & -0.017 & 1.531 & 0.907 & 0.026 & 14.563 & -0.016 \\
\hline
\end{tabular}




\begin{tabular}{ccccccccccc}
8 & 1.438 & 0.874 & 0.037 & 11.762 & -0.018 & 1.443 & 0.870 & 0.037 & 16.022 & -0.030 \\
10 & 1.382 & 0.858 & 0.040 & 14.389 & -0.022 & 1.377 & 0.854 & 0.042 & 12.741 & -0.020 \\
15 & 1.287 & 0.837 & 0.047 & 15.238 & -0.030 & 1.280 & 0.837 & 0.047 & 14.811 & -0.028 \\
\hline
\end{tabular}

Table 4: GP fitting parameters for epirubicin in the energy range $0.015-15 \mathrm{MeV}$

\begin{tabular}{|c|c|c|c|c|c|c|c|c|c|c|}
\hline \multirow{2}{*}{ Energy $(\mathrm{MeV})$} & \multicolumn{5}{|c|}{ EABF } & \multicolumn{5}{|c|}{ EBF } \\
\hline & b & c & $\mathbf{a}$ & $\mathbf{X k}$ & d & b & c & $\mathbf{a}$ & $\mathbf{X k}$ & d \\
\hline 0.015 & 1.292 & 0.499 & 0.160 & 14.518 & -0.078 & 1.286 & 0.497 & 0.162 & 14.284 & -0.081 \\
\hline 0.02 & 1.677 & 0.634 & 0.114 & 15.440 & -0.056 & 1.659 & 0.637 & 0.112 & 15.544 & -0.055 \\
\hline 0.03 & 3.081 & 0.956 & 0.023 & 14.782 & -0.021 & 2.945 & 0.955 & 0.024 & 14.657 & -0.022 \\
\hline 0.04 & 4.400 & 1.450 & -0.080 & 13.915 & 0.032 & 4.450 & 1.458 & -0.082 & 13.707 & 0.034 \\
\hline 0.05 & 5.176 & 1.806 & -0.132 & 14.170 & 0.056 & 5.711 & 1.829 & -0.136 & 14.048 & 0.059 \\
\hline 0.06 & 5.261 & 2.073 & -0.166 & 14.143 & 0.073 & 6.222 & 2.124 & -0.172 & 14.036 & 0.078 \\
\hline 0.08 & 4.890 & 2.342 & -0.194 & 14.045 & 0.083 & 6.040 & 2.465 & -0.209 & 13.808 & 0.094 \\
\hline 0.1 & 4.495 & 2.388 & -0.195 & 14.666 & 0.080 & 5.526 & 2.561 & -0.213 & 14.395 & 0.093 \\
\hline 0.15 & 3.636 & 2.395 & -0.197 & 14.684 & 0.078 & 4.175 & 2.659 & -0.227 & 14.125 & 0.100 \\
\hline 0.2 & 3.266 & 2.283 & -0.188 & 14.784 & 0.076 & 3.579 & 2.558 & -0.221 & 14.231 & 0.098 \\
\hline 0.3 & 2.817 & 2.095 & -0.172 & 14.613 & 0.068 & 3.061 & 2.287 & -0.197 & 14.248 & 0.086 \\
\hline 0.4 & 2.625 & 1.913 & -0.152 & 14.554 & 0.062 & 2.778 & 2.097 & -0.179 & 13.733 & 0.075 \\
\hline 0.5 & 2.459 & 1.794 & -0.138 & 15.185 & 0.059 & 2.604 & 1.932 & -0.160 & 14.163 & 0.071 \\
\hline 0.6 & 2.383 & 1.671 & -0.121 & 14.650 & 0.048 & 2.482 & 1.800 & -0.143 & 13.827 & 0.059 \\
\hline 0.8 & 2.200 & 1.555 & -0.107 & 14.139 & 0.045 & 2.281 & 1.642 & -0.124 & 13.902 & 0.057 \\
\hline 1 & 2.096 & 1.447 & -0.090 & 14.430 & 0.038 & 2.161 & 1.513 & -0.104 & 13.864 & 0.049 \\
\hline 1.5 & 1.938 & 1.276 & -0.060 & 14.315 & 0.026 & 1.999 & 1.300 & -0.066 & 14.001 & 0.031 \\
\hline 2 & 1.841 & 1.169 & -0.038 & 14.403 & 0.015 & 1.889 & 1.188 & -0.043 & 13.981 & 0.020 \\
\hline 3 & 1.714 & 1.051 & -0.011 & 14.104 & 0.003 & 1.745 & 1.059 & -0.014 & 12.385 & 0.006 \\
\hline 4 & 1.627 & 0.988 & 0.004 & 13.123 & -0.003 & 1.649 & 0.987 & 0.004 & 23.623 & -0.007 \\
\hline 5 & 1.565 & 0.944 & 0.015 & 14.740 & -0.008 & 1.572 & 0.939 & 0.017 & 14.315 & -0.011 \\
\hline 6 & 1.514 & 0.907 & 0.028 & 13.308 & -0.018 & 1.523 & 0.907 & 0.027 & 13.980 & -0.016 \\
\hline 8 & 1.430 & 0.881 & 0.034 & 12.096 & -0.017 & 1.437 & 0.872 & 0.037 & 16.010 & -0.031 \\
\hline 10 & 1.375 & 0.861 & 0.040 & 14.322 & -0.022 & 1.371 & 0.859 & 0.041 & 12.715 & -0.021 \\
\hline 15 & 1.281 & 0.838 & 0.047 & 15.732 & -0.033 & 1.275 & 0.841 & 0.046 & 15.225 & -0.030 \\
\hline
\end{tabular}

Table 5: GP fitting parameters for gemcitabine in the energy range $0.015-15 \mathrm{MeV}$

\begin{tabular}{|c|c|c|c|c|c|c|c|c|c|c|}
\hline \multirow[t]{2}{*}{ Energy (MeV) } & \multicolumn{5}{|c|}{ EABF } & \multicolumn{5}{|c|}{ EBF } \\
\hline & b & c & $\mathbf{a}$ & $\mathbf{X k}$ & d & b & c & $\mathbf{a}$ & $\mathbf{X k}$ & d \\
\hline 0.015 & 1.228 & 0.479 & 0.166 & 14.429 & -0.081 & 1.226 & 0.471 & 0.173 & 14.292 & -0.087 \\
\hline 0.02 & 1.538 & 0.570 & 0.137 & 14.855 & -0.068 & 1.523 & 0.577 & 0.133 & 14.963 & -0.065 \\
\hline 0.03 & 2.657 & 0.824 & 0.059 & 15.588 & -0.038 & 2.563 & 0.829 & 0.056 & 15.778 & -0.040 \\
\hline 0.04 & 3.914 & 1.246 & -0.045 & 13.748 & 0.014 & 3.871 & 1.253 & -0.047 & 13.568 & 0.016 \\
\hline 0.05 & 4.838 & 1.606 & -0.107 & 13.918 & 0.045 & 4.964 & 1.614 & -0.109 & 13.826 & 0.047 \\
\hline 0.06 & 5.119 & 1.896 & -0.148 & 13.764 & 0.069 & 5.454 & 1.913 & -0.151 & 13.684 & 0.070 \\
\hline 0.08 & 4.914 & 2.213 & -0.185 & 13.441 & 0.105 & 5.407 & 2.268 & -0.192 & 13.316 & 0.110 \\
\hline 0.1 & 4.660 & 2.245 & -0.183 & 14.466 & 0.089 & 5.195 & 2.326 & -0.191 & 14.380 & 0.082 \\
\hline 0.15 & 3.745 & 2.302 & -0.189 & 14.420 & 0.077 & 3.977 & 2.461 & -0.210 & 14.111 & 0.095 \\
\hline 0.2 & 3.357 & 2.202 & -0.180 & 14.799 & 0.076 & 3.410 & 2.420 & -0.209 & 13.395 & 0.090 \\
\hline 0.3 & 2.838 & 2.061 & -0.168 & 14.259 & 0.067 & 2.974 & 2.160 & -0.182 & 14.083 & 0.077 \\
\hline 0.4 & 2.621 & 1.900 & -0.151 & 14.259 & 0.060 & 2.711 & 1.993 & -0.165 & 14.005 & 0.070 \\
\hline 0.5 & 2.461 & 1.786 & -0.138 & 14.283 & 0.056 & 2.548 & 1.850 & -0.148 & 14.135 & 0.063 \\
\hline 0.6 & 2.366 & 1.679 & -0.124 & 14.305 & 0.050 & 2.418 & 1.747 & -0.135 & 14.065 & 0.058 \\
\hline 0.8 & 2.202 & 1.546 & -0.105 & 14.190 & 0.044 & 2.247 & 1.590 & -0.114 & 14.009 & 0.050 \\
\hline 1 & 2.106 & 1.432 & -0.087 & 14.672 & 0.036 & 2.129 & 1.480 & -0.097 & 13.953 & 0.044 \\
\hline 1.5 & 1.934 & 1.276 & -0.060 & 14.355 & 0.026 & 1.980 & 1.282 & -0.061 & 14.493 & 0.027 \\
\hline
\end{tabular}




\begin{tabular}{ccccccccccc}
2 & 1.838 & 1.173 & -0.039 & 14.151 & 0.017 & 1.872 & 1.182 & -0.041 & 13.964 & 0.019 \\
3 & 1.711 & 1.054 & -0.012 & 13.224 & 0.004 & 1.730 & 1.060 & -0.014 & 13.243 & 0.005 \\
4 & 1.628 & 0.984 & 0.006 & 13.777 & -0.005 & 1.639 & 0.988 & 0.004 & 19.265 & -0.006 \\
5 & 1.566 & 0.937 & 0.018 & 14.068 & -0.012 & 1.567 & 0.940 & 0.018 & 13.913 & -0.012 \\
6 & 1.504 & 0.922 & 0.022 & 15.397 & -0.017 & 1.520 & 0.904 & 0.029 & 13.151 & -0.017 \\
8 & 1.430 & 0.874 & 0.037 & 12.066 & -0.021 & 1.429 & 0.880 & 0.035 & 13.645 & -0.023 \\
10 & 1.369 & 0.866 & 0.039 & 14.326 & -0.022 & 1.365 & 0.866 & 0.039 & 13.530 & -0.022 \\
15 & 1.276 & 0.839 & 0.048 & 15.335 & -0.034 & 1.273 & 0.841 & 0.047 & 15.125 & -0.032 \\
\hline
\end{tabular}

Table 6: GP fitting parameters for ifosfamide in the energy range $0.015-15 \mathrm{MeV}$

\begin{tabular}{|c|c|c|c|c|c|c|c|c|c|c|}
\hline \multirow[t]{2}{*}{ Energy (MeV) } & \multicolumn{5}{|c|}{ EABF } & \multicolumn{5}{|c|}{ EBF } \\
\hline & $\mathbf{b}$ & c & $\mathbf{a}$ & $\mathbf{X k}$ & d & $\mathbf{b}$ & c & $\mathbf{a}$ & $\mathbf{X k}$ & d \\
\hline 0.015 & 1.039 & 0.402 & 0.209 & 13.063 & -0.127 & 1.039 & 0.398 & 0.213 & 13.098 & -0.131 \\
\hline 0.02 & 1.087 & 0.428 & 0.183 & 14.507 & -0.094 & 1.086 & 0.438 & 0.179 & 14.318 & -0.092 \\
\hline 0.03 & 1.288 & 0.442 & 0.192 & 14.242 & -0.102 & 1.282 & 0.447 & 0.190 & 14.444 & -0.102 \\
\hline 0.04 & 1.625 & 0.548 & 0.146 & 15.245 & -0.077 & 1.598 & 0.550 & 0.146 & 15.117 & -0.078 \\
\hline 0.05 & 2.175 & 0.615 & 0.133 & 13.753 & -0.072 & 2.050 & 0.638 & 0.121 & 14.471 & -0.063 \\
\hline 0.06 & 2.732 & 0.767 & 0.081 & 13.357 & -0.056 & 2.429 & 0.781 & 0.075 & 14.637 & -0.057 \\
\hline 0.08 & 3.748 & 1.048 & 0.002 & 14.331 & -0.016 & 2.926 & 1.030 & 0.007 & 13.644 & -0.021 \\
\hline 0.1 & 4.267 & 1.285 & -0.049 & 12.623 & 0.008 & 3.101 & 1.229 & -0.035 & 12.292 & -0.004 \\
\hline 0.15 & 4.088 & 1.619 & -0.107 & 13.330 & 0.039 & 3.064 & 1.478 & -0.079 & 15.006 & 0.016 \\
\hline 0.2 & 3.636 & 1.721 & -0.122 & 13.723 & 0.044 & 2.897 & 1.570 & -0.094 & 15.490 & 0.023 \\
\hline 0.3 & 3.037 & 1.743 & -0.126 & 13.991 & 0.046 & 2.634 & 1.605 & -0.101 & 15.270 & 0.026 \\
\hline 0.4 & 2.729 & 1.688 & -0.120 & 14.211 & 0.042 & 2.469 & 1.575 & -0.099 & 15.188 & 0.027 \\
\hline 0.5 & 2.541 & 1.628 & -0.113 & 14.286 & 0.040 & 2.343 & 1.540 & -0.096 & 15.076 & 0.029 \\
\hline 0.6 & 2.404 & 1.565 & -0.103 & 14.563 & 0.036 & 2.249 & 1.494 & -0.089 & 15.400 & 0.026 \\
\hline 0.8 & 2.228 & 1.467 & -0.090 & 14.856 & 0.032 & 2.115 & 1.419 & -0.080 & 15.223 & 0.025 \\
\hline 1 & 2.112 & 1.386 & -0.077 & 14.872 & 0.028 & 2.021 & 1.356 & -0.070 & 15.699 & 0.023 \\
\hline 1.5 & 1.937 & 1.255 & -0.054 & 14.286 & 0.021 & 1.890 & 1.241 & -0.051 & 15.049 & 0.018 \\
\hline 2 & 1.843 & 1.159 & -0.035 & 14.701 & 0.013 & 1.811 & 1.158 & -0.035 & 14.792 & 0.013 \\
\hline 3 & 1.708 & 1.053 & -0.010 & 12.225 & 0.000 & 1.696 & 1.054 & -0.011 & 11.500 & 0.001 \\
\hline 4 & 1.617 & 0.984 & 0.008 & 13.076 & -0.010 & 1.614 & 0.991 & 0.005 & 16.231 & -0.008 \\
\hline 5 & 1.548 & 0.944 & 0.019 & 12.944 & -0.014 & 1.544 & 0.952 & 0.002 & 14.850 & -0.016 \\
\hline 6 & 1.491 & 0.919 & 0.026 & 15.568 & -0.027 & 1.499 & 0.915 & 0.006 & 13.305 & -0.024 \\
\hline 8 & 1.398 & 0.900 & 0.032 & 12.303 & -0.020 & 1.411 & 0.897 & 0.003 & 12.969 & -0.023 \\
\hline 10 & 1.339 & 0.882 & 0.038 & 13.916 & -0.028 & 1.352 & 0.874 & 0.005 & 13.557 & -0.030 \\
\hline 15 & 1.241 & 0.872 & 0.043 & 14.734 & -0.034 & 1.264 & 0.832 & 0.058 & 14.664 & -0.048 \\
\hline
\end{tabular}

Table 7: GP fitting parameters for methotrexate in the energy range $0.015-15 \mathrm{MeV}$

\begin{tabular}{|c|c|c|c|c|c|c|c|c|c|c|}
\hline \multirow{2}{*}{ Energy $(\mathrm{MeV})$} & \multicolumn{5}{|c|}{ EABF } & \multicolumn{5}{|c|}{ EBF } \\
\hline & b & c & $\mathbf{a}$ & $\mathbf{X k}$ & d & b & c & $\mathbf{a}$ & $\mathbf{X k}$ & d \\
\hline 0.015 & 1.312 & 0.504 & 0.158 & 14.500 & -0.078 & 1.305 & 0.505 & 0.159 & 14.289 & -0.079 \\
\hline 0.02 & 1.720 & 0.654 & 0.107 & 15.635 & -0.052 & 1.700 & 0.655 & 0.106 & 15.740 & -0.052 \\
\hline 0.03 & 3.210 & 0.996 & 0.013 & 14.338 & -0.015 & 3.059 & 0.995 & 0.014 & 14.288 & -0.016 \\
\hline 0.04 & 4.540 & 1.509 & -0.090 & 13.954 & 0.037 & 4.619 & 1.518 & -0.092 & 13.749 & 0.039 \\
\hline 0.05 & 5.265 & 1.861 & -0.139 & 14.236 & 0.059 & 5.923 & 1.888 & -0.143 & 14.110 & 0.062 \\
\hline 0.06 & 5.297 & 2.120 & -0.170 & 14.255 & 0.074 & 6.436 & 2.180 & -0.178 & 14.143 & 0.080 \\
\hline 0.08 & 4.884 & 2.375 & -0.196 & 14.214 & 0.083 & 6.207 & 2.515 & -0.213 & 13.948 & 0.095 \\
\hline 0.1 & 4.452 & 2.424 & -0.198 & 14.714 & 0.081 & 5.608 & 2.620 & -0.219 & 14.396 & 0.095 \\
\hline 0.15 & 3.610 & 2.417 & -0.199 & 14.748 & 0.078 & 4.222 & 2.707 & -0.232 & 14.128 & 0.102 \\
\hline 0.2 & 3.244 & 2.302 & -0.190 & 14.781 & 0.075 & 3.619 & 2.591 & -0.224 & 14.430 & 0.100 \\
\hline 0.3 & 2.813 & 2.103 & -0.173 & 14.695 & 0.068 & 3.082 & 2.317 & -0.200 & 14.287 & 0.088 \\
\hline 0.4 & 2.626 & 1.916 & -0.152 & 14.623 & 0.062 & 2.794 & 2.121 & -0.182 & 13.670 & 0.077 \\
\hline
\end{tabular}




\begin{tabular}{ccccccccccc}
0.5 & 2.458 & 1.796 & -0.138 & 15.394 & 0.060 & 2.617 & 1.951 & -0.162 & 14.170 & 0.073 \\
0.6 & 2.387 & 1.669 & -0.121 & 14.730 & 0.047 & 2.497 & 1.813 & -0.145 & 13.772 & 0.060 \\
0.8 & 2.199 & 1.557 & -0.108 & 14.127 & 0.045 & 2.288 & 1.654 & -0.126 & 13.877 & 0.059 \\
1 & 2.094 & 1.450 & -0.091 & 14.374 & 0.039 & 2.169 & 1.521 & -0.105 & 13.844 & 0.050 \\
1.5 & 1.939 & 1.275 & -0.060 & 14.307 & 0.027 & 2.003 & 1.303 & -0.067 & 13.901 & 0.032 \\
2 & 1.842 & 1.168 & -0.037 & 14.452 & 0.015 & 1.893 & 1.190 & -0.043 & 13.985 & 0.020 \\
3 & 1.714 & 1.051 & -0.011 & 14.272 & 0.003 & 1.748 & 1.058 & -0.014 & 12.222 & 0.006 \\
4 & 1.626 & 0.989 & 0.003 & 12.999 & -0.003 & 1.650 & 0.986 & 0.004 & 24.450 & -0.008 \\
5 & 1.564 & 0.945 & 0.015 & 14.868 & -0.008 & 1.573 & 0.939 & 0.017 & 14.391 & -0.011 \\
6 & 1.516 & 0.904 & 0.029 & 12.913 & -0.018 & 1.524 & 0.907 & 0.026 & 14.137 & -0.015 \\
8 & 1.430 & 0.882 & 0.034 & 12.102 & -0.017 & 1.438 & 0.870 & 0.037 & 16.455 & -0.033 \\
10 & 1.376 & 0.860 & 0.040 & 14.321 & -0.022 & 1.372 & 0.857 & 0.041 & 12.562 & -0.021 \\
15 & 1.282 & 0.838 & 0.047 & 15.805 & -0.033 & 1.275 & 0.841 & 0.046 & 15.244 & -0.030 \\
\hline
\end{tabular}

Table 8: GP fitting parameters for paclitaxel in the energy range $0.015-15 \mathrm{MeV}$

\begin{tabular}{|c|c|c|c|c|c|c|c|c|c|c|}
\hline \multirow[t]{2}{*}{ Energy (MeV) } & \multicolumn{5}{|c|}{ EABF } & \multicolumn{5}{|c|}{ EBF } \\
\hline & b & c & $\mathbf{a}$ & $\mathbf{X k}$ & d & b & c & $\mathbf{a}$ & $\mathbf{X k}$ & d \\
\hline 0.015 & 1.323 & 0.507 & 0.158 & 14.490 & -0.078 & 1.315 & 0.509 & 0.158 & 14.291 & -0.078 \\
\hline 0.02 & 1.742 & 0.665 & 0.103 & 15.739 & -0.050 & 1.723 & 0.665 & 0.103 & 15.844 & -0.050 \\
\hline 0.03 & 3.279 & 1.016 & 0.008 & 14.103 & -0.012 & 3.119 & 1.016 & 0.008 & 14.093 & -0.013 \\
\hline 0.04 & 4.616 & 1.542 & -0.095 & 13.975 & 0.039 & 4.711 & 1.551 & -0.097 & 13.772 & 0.041 \\
\hline 0.05 & 5.317 & 1.893 & -0.143 & 14.274 & 0.061 & 6.046 & 1.923 & -0.147 & 14.146 & 0.064 \\
\hline 0.06 & 5.318 & 2.148 & -0.173 & 14.324 & 0.075 & 6.568 & 2.215 & -0.181 & 14.209 & 0.082 \\
\hline 0.08 & 4.880 & 2.396 & -0.198 & 14.330 & 0.083 & 6.321 & 2.549 & -0.216 & 14.043 & 0.096 \\
\hline 0.1 & 4.421 & 2.450 & -0.201 & 14.750 & 0.081 & 5.668 & 2.663 & -0.223 & 14.397 & 0.097 \\
\hline 0.15 & 3.588 & 2.435 & -0.200 & 14.801 & 0.079 & 4.262 & 2.746 & -0.235 & 14.131 & 0.103 \\
\hline 0.2 & 3.224 & 2.319 & -0.191 & 14.778 & 0.075 & 3.655 & 2.620 & -0.226 & 14.608 & 0.101 \\
\hline 0.3 & 2.808 & 2.111 & -0.173 & 14.775 & 0.069 & 3.101 & 2.346 & -0.203 & 14.324 & 0.090 \\
\hline 0.4 & 2.627 & 1.919 & -0.153 & 14.691 & 0.062 & 2.809 & 2.145 & -0.185 & 13.607 & 0.078 \\
\hline 0.5 & 2.457 & 1.797 & -0.138 & 15.606 & 0.060 & 2.630 & 1.971 & -0.165 & 14.176 & 0.075 \\
\hline 0.6 & 2.391 & 1.667 & -0.120 & 14.812 & 0.047 & 2.512 & 1.825 & -0.147 & 13.716 & 0.060 \\
\hline 0.8 & 2.199 & 1.559 & -0.108 & 14.115 & 0.045 & 2.296 & 1.666 & -0.128 & 13.852 & 0.061 \\
\hline 1 & 2.092 & 1.454 & -0.091 & 14.316 & 0.039 & 2.177 & 1.528 & -0.107 & 13.822 & 0.051 \\
\hline 1.5 & 1.941 & 1.275 & -0.060 & 14.293 & 0.027 & 2.010 & 1.310 & -0.069 & 13.729 & 0.033 \\
\hline 2 & 1.843 & 1.167 & -0.037 & 14.518 & 0.014 & 1.900 & 1.193 & -0.044 & 14.003 & 0.021 \\
\hline 3 & 1.715 & 1.050 & -0.011 & 14.451 & 0.003 & 1.753 & 1.058 & -0.014 & 12.013 & 0.006 \\
\hline 4 & 1.626 & 0.990 & 0.003 & 12.920 & -0.002 & 1.654 & 0.986 & 0.004 & 25.241 & -0.008 \\
\hline 5 & 1.564 & 0.947 & 0.014 & 14.992 & -0.007 & 1.576 & 0.939 & 0.017 & 14.521 & -0.011 \\
\hline 6 & 1.519 & 0.900 & 0.030 & 12.390 & -0.018 & 1.526 & 0.908 & 0.026 & 14.387 & -0.015 \\
\hline 8 & 1.431 & 0.883 & 0.034 & 12.061 & -0.016 & 1.440 & 0.868 & 0.038 & 16.930 & -0.034 \\
\hline 10 & 1.379 & 0.859 & 0.040 & 14.330 & -0.022 & 1.374 & 0.855 & 0.042 & 12.407 & -0.021 \\
\hline 15 & 1.284 & 0.838 & 0.047 & 15.811 & -0.032 & 1.277 & 0.840 & 0.046 & 15.202 & -0.029 \\
\hline
\end{tabular}

The variation of EABF and EBF values with incident photon energy for anastrozole, epirubicin, gemcitabine, ifosfamide, methotrexate and paclitaxel at some chosen penetration depth were plotted in Figs. 3 and 4, respectively. It was monitored that the EABF and EBF values of the studied drugs at 1, 5, 10 and $40 \mathrm{mfp}$, increased with increasing energy, reached the maximum value in the intermediate energies and then decreased again in the further energies. As can be seen from Figs. 3 and 4, the EABF and 
EBF values of ifosfamide are smaller than EABF and EBF values of other drugs. The maximum EABF and EBF values were seen at the $0.3 \mathrm{MeV}$ photon energy for ifosfamide and $0.1 \mathrm{MeV}$ photon energy for anastrozole, epirubicin, gemcitabine, methotrexate and paclitaxel. This trend observed in EABF and EBF values can be explained on the basis that while Compton scattering is the dominant interaction mechanism in the medium energy region, photoelectric absorption and pair production are the dominant interaction mechanisms in the low and high energy region, respectively. On the other hand, this trend is also in line with the observation of Sayyed et al. [32] who estimated photon buildup factors of some anti-inflammatory drugs. It was also seen that the values of EABF and EBF increased with increasing depth of penetration and became very high for the greatest at penetration depth $40 \mathrm{mfp}$. This increase is a result of multiple scattering events for large penetration depths [17].
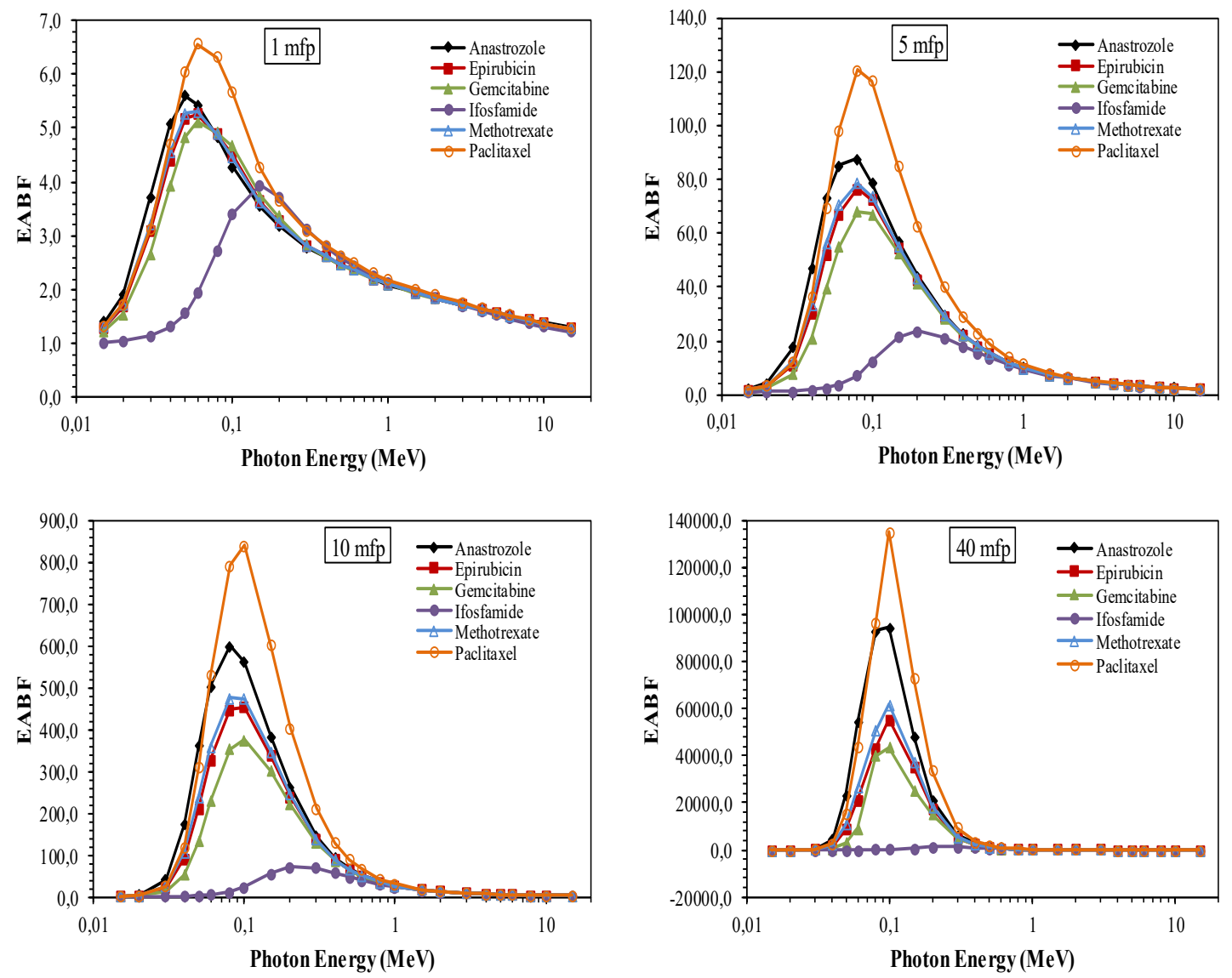

Figure 3: The EABF values of drugs in the energy range of $0.015-15 \mathrm{MeV}$ at $1,5,10$ and $40 \mathrm{mfp}$ 

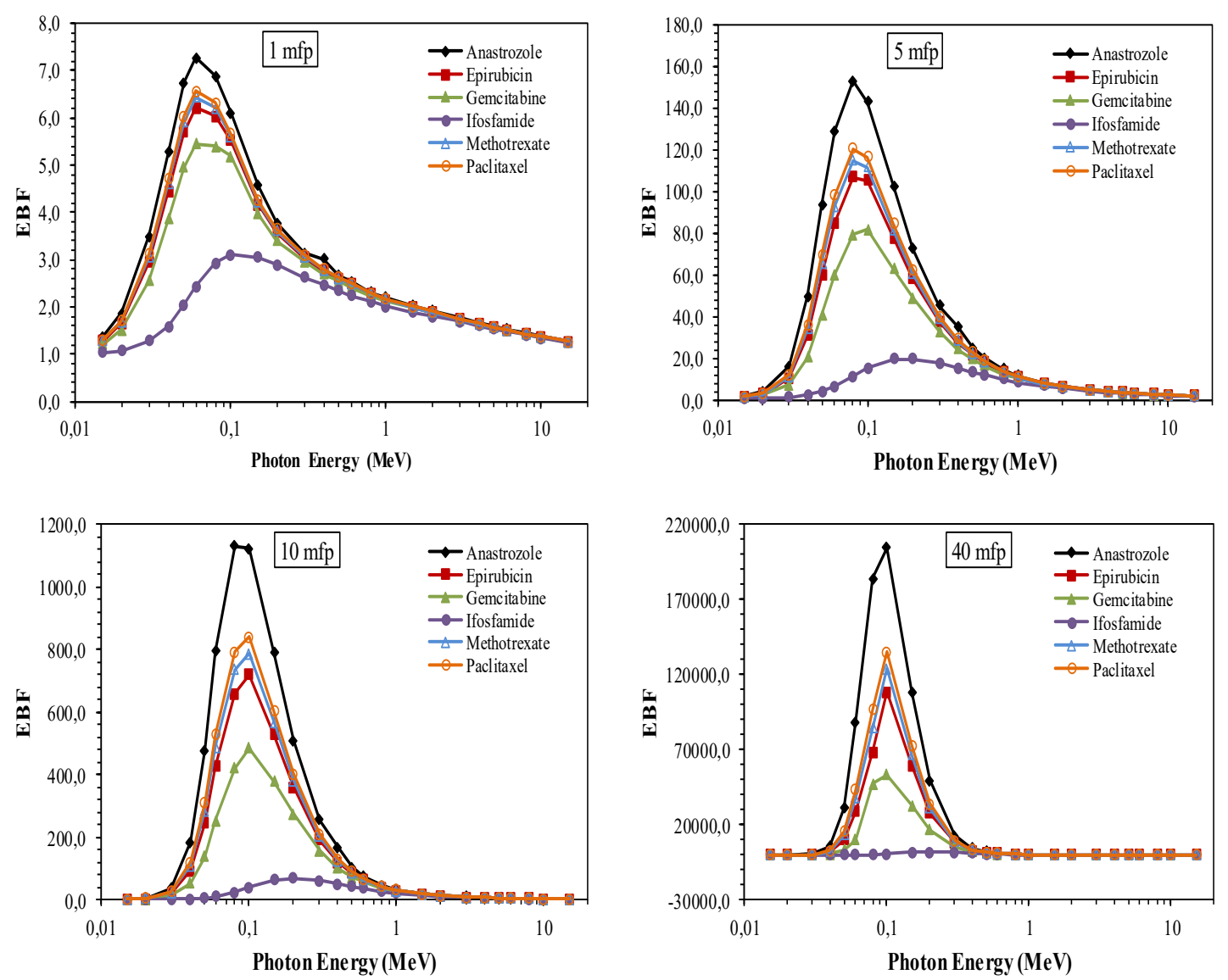

Figure 4: The EBF values of drugs in the energy range of $0.015-15 \mathrm{MeV}$ at 1, 5, 10 and $40 \mathrm{mfp}$

The EABF and EBF values of the investigated anti neoplastic chemotherapy drugs against the mfp for $0.015,0.15,1.5$ and $15 \mathrm{MeV}$ photon energies are given in Figs. 5 and 6, respectively. From Figs. 5 and 6, it was observed that the EABF and EBF values of the studied chemotherapy drugs increased with the increase in mfp values. It is clear from these figures that EABF and EBF values of the investigated drugs at 0.15 and $1.5 \mathrm{MeV}$ energies are higher than the others. It was seen that ifosfamide, which has the highest $Z_{\mathrm{eq}}$ value, has the smallest EABF and EBF values at low energies (0.015 and $0.15 \mathrm{MeV})$. On the other hand, Anastrozole has the highest EABF and EBF values at 0.015 and $0.15 \mathrm{MeV}$ photon energies owing to its low $Z_{\mathrm{eq}}$ value. Also, the $\mathrm{EABF}$ and $\mathrm{EBF}$ values of ifosfamide remains nearly constant at $0.015 \mathrm{MeV}$ energy, while the EABF and EBF values of other drugs increase with increasing mpf values. At $0.15 \mathrm{MeV}$, EABF and EBF values of the studied chemotherapy drugs increased with the rising up in mfp values. The maximum values were observed for anastrozole and paclitaxel and minimum value was observed for ifosfamide in this energy. It was seen that the EABF and EBF values of drug samples 
decreased with the increasing $\mathrm{Z}_{\mathrm{eq}}$ values at lower than the $0.15 \mathrm{MeV}$, because the cross section of photoelectric absorption, which is the effective interaction process at low energies, is strongly dependent on $\mathrm{Z}_{\mathrm{eq}}{ }^{4-5}$. Contrary to others, the EABF and EBF values for $1.5 \mathrm{MeV}$ photon energy are almost independent of the chemical composition (i.e. $Z_{\mathrm{eq}}$ ) of the drugs as reported by Kavaz et al. [34]. This result can be clarified by the predominance of Compton scattering at $1.5 \mathrm{MeV}$ energy. As can be seen from Figs. 5 and 6, the values of EABF and EBF of the drugs increase with increase in $Z_{\text {eq }}$ at $15 \mathrm{MeV}$ between 10 and $40 \mathrm{mfp}$ and ifosfamide showed higher values than other drugs due to the dominance of pair production in this region. This result is agreeing with the findings reported by Kavaz et al. [42] who evaluated EABF and EBF factors of some radio protective agents.
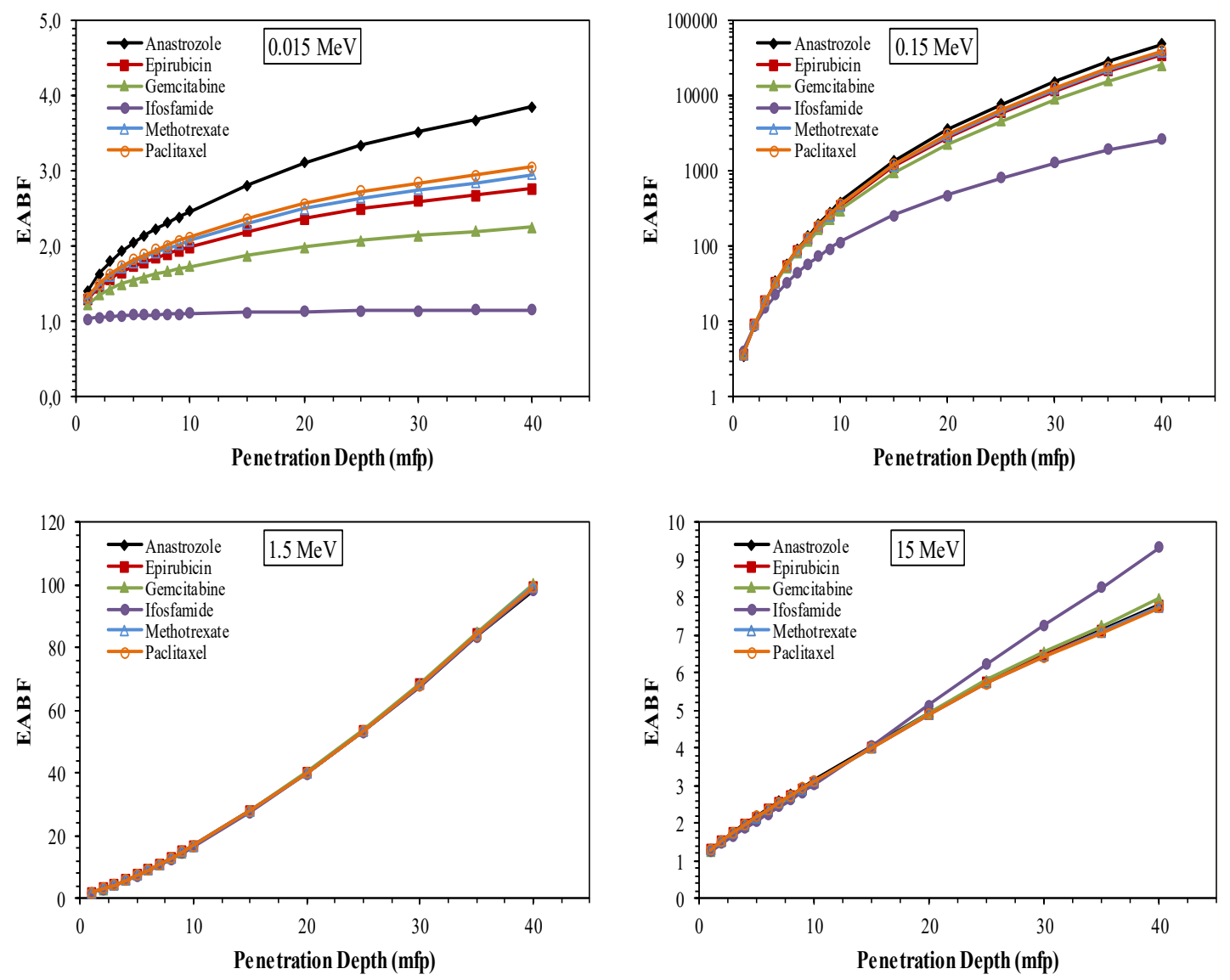

Figure 5: The energy absorption buildup factor for the drugs up to $40 \mathrm{mfp}$ at $0.015,0.15,1.5$ and $15 \mathrm{MeV}$ 

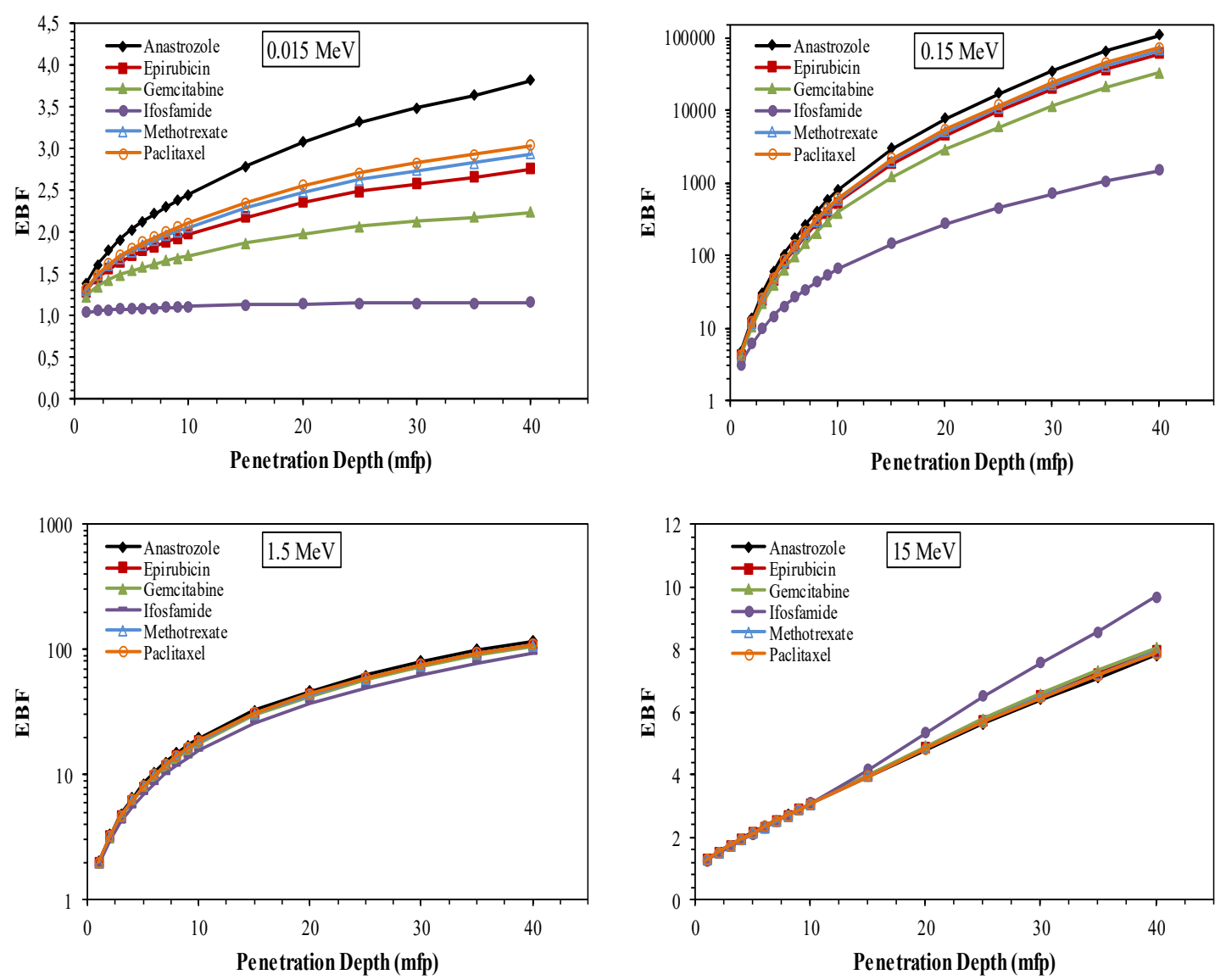

Figure 6: The energy exposure buildup factor for the drugs up to $40 \mathrm{mfp}$ at $0,015,0.15,1.5$ and $15 \mathrm{MeV}$

\section{Conclusion}

The present study was carried out to obtain information on photon interaction parameters of different antineoplastic chemotherapy drugs. The energy absorption buildup factors and exposure buildup factors of anastrozole $\left(\mathrm{C}_{17} \mathrm{H}_{19} \mathrm{~N}_{5}\right)$, epirubicin $\left(\mathrm{C}_{27} \mathrm{H}_{26} \mathrm{NO}_{11}\right)$, gemcitabine $\left(\mathrm{C}_{9} \mathrm{H}_{11} \mathrm{~F}_{2} \mathrm{~N}_{3} \mathrm{O}_{4}\right)$, ifosfamide $\left(\mathrm{C}_{7} \mathrm{H}_{15} \mathrm{Cl}_{12} \mathrm{~N}_{2} \mathrm{O}_{2} \mathrm{P}\right)$, methotrexate $\left(\mathrm{C}_{20} \mathrm{H}_{22} \mathrm{~N}_{8} \mathrm{O}_{5}\right)$ and paclitaxel $\left(\mathrm{C}_{47} \mathrm{H}_{51} \mathrm{NO}_{14}\right)$ chemotherapy drugs were computed using GP fitting method. Also, $Z_{\text {eff }}$ and $\mathrm{N}_{\mathrm{el}}$ values were determined with the help of the WinXCOM program for photon energies from $1 \mathrm{keV}$ to $100 \mathrm{GeV}$. The results obtained in this study showed that $Z_{\text {eff }}$ and $N_{\mathrm{el}}$ values are dependent on the photon energy. The highest $Z_{\text {eff }}$ values were found for ifosfamide and the lowest $Z_{\text {eff }}$ values for anastrozole. This study also showed that buildup factors vary depending on the chemical composition (i.e. $Z_{\mathrm{eq}}$ ) of the drugs, photon energy and mean free path. Among the studied samples, ifosfamide has the largest buildup factor values at $15 \mathrm{MeV}$ photon energy, while it has the smallest values at $0.015,0.15$ and $1.5 \mathrm{MeV}$ photon energies. It was concluded that ifosfamide has 
better photon absorption properties since it contains phosphorus and chlorine in its chemical structure, unlike other drugs. It is predictable that the results of this work will be beneficial in areas such as radiation dosimetry and chemoradiotherapy.

\section{References}

[1] Oto, B., Oto, G., Madak, Z., Kavaz, E., The interaction of gamma radiation with drugs used in cholinergic medications, Journal of Radiation Biology, 96(2), 236-244, 2020.

[2] Yorgun,N.Y., Kavaz, E., Gamma photon protection properties of some cancer drugs for medical applications. Results in Physics, 13 (102150), 1-6, 2019.

[3] Veranda, E., Tavares, D., Radioprotection mechanisms and radioprotective agents, including honeybee venom, Journal of Venomous Animals and Toxins, 4(1), 5-20, 1988.

[4] Sayyed, M.I., Kaky, K.M., Şakar, E., Akbaba, U., Taki, M.M., Agar, O., Gamma radiation shielding investigations for selected germanate glasses, Journal of Non-Crystalline Solids, 512, 33-40, 2019.

[5] Manohara, S.R., Hanagotimath. S.M., Gerward, L. Energy absorption buildup factors of human organs and tissues at energies and penetration depths relevant for radiotherapy and diagnostics, Journal of Applied Clinical Medical Physics, 12, 3557-3566, 2011.

[6] Singh, S.P., Singh, T., Kaur, P., Variation of energy absorption buildup factors with incident photon energy and penetration depth for some commonly used solvents, Annals of Nuclear Energy, 35, 1093-1097, 2008.

[7] Harima, Y., Sakamoto, Y., Tanaka, S., Kawai, M. Validity of the geometric progression formula in approximating gamma ray buildup factors, Nuclear Science and Engineering, 94, 24$35,1986$.

[8] Shimizu, A., Calculations of gamma ray buildup factors up to depths of $100 \mathrm{mfp}$ by the method of invariant embedding, (I) analysis of accuracy and comparison with other data, Journal of Nuclear Science and Technology, 39, 477-486, 2002.

[9] Suteau, C., Chiron, M., An iterative method for calculating gamma ray buildup factors in multi-layer shields, Radiation Protection Dosimetry, 116, 489-492, 2005.

[10] Sardari, D., Saudi, S., Tajik, M., Evaluation of gamma ray buildup factor data in water with MCNP4C code, Annals of Nuclear Energy, 38(23), 628-631, 2011.

[11] Harima Y., An approximation of gamma ray buildup factors by modified geometrical progression, Nuclear Science and Engineering, 83, 299-309, 1983.

[12] Singh, V.P., Badiger, N.M., Investigation on radiation shielding parameters of ordinary, heavy and super heavy concretes, Nuclear Technology and Radiation Protection 29, 149-156, 2014.

[13] Şakar, E., Büyükyıldız, M., Alım, B., Şakar, B.C., Kurudirek, M., Leaded brass alloys for gamma-ray shielding applications, Radiation Physics and Chemistry, 159, 64-69, 2019.

[14] Şakar, E., Determination of photon-shielding features and build-up factors of nickelsilver alloys, Radiation Physics and Chemistry, 172, 108778, 2021. 
[15] Kaur, P., Singh, D., Singh, T., Gamma ray shielding and sensing application of some rare earth doped lead-alumino-phosphate glasses, Radiation Physics and Chemistry, 144, 336$343,2018$.

[16] Rammah, Y.S., Özpolat, Ö.F., Alım, B., Şakar, E., El-Mallawany, R., El-Agawany F.I., Assessment of gamma-ray attenuation features for $\mathrm{La}^{+3}$ co-doped zinc borotellurite glasses, Radiation Physics and Chemistry, 176, 109069, 2020.

[17] Sayyed, M., AlZaatreh, M., Matori, K., Sidek, H., Zaid, M., Comprehensive study on estimation of gamma ray exposure buildup factors for smart polymers as a potent application in nuclear industries, Results in Physics, 9, 585-592, 2018.

[18] Sharaf, J.M., Saleh, H., Gamma-ray energy buildup factor calculations and shielding effects of some Jordanian building structures, Radiation Physics and Chemistry, 110, 87-95, 2015.

[19] Manjunatha, H.C., Rudraswamy, B., Computation of exposure build-up factors in teeth, Radiation Physics and Chemistry, 80 (1), 14-21, 2011.

[20] Kurudirek, M., Topcuoglu, S., Investigation of human teeth with respect to the photon interaction, energy absorption and buildup factor, Nuclear Instruments and Methods in Physics Research B, 269, 1071-1081, 2011.

[21]. Yilmaz, D., Gedik, Z., Tugrak, M., Gul, H.I., Energy absorption buildup factors of some potential bioactive compounds in the energy region 0.015-15 MeV, Spectroscopy Letters, 50(6), 301-306, 2017.

[22] Bursalıglu, E., Balkan, B., Kavanoz, H.B., Okutan, M., Icelli, O., Yalcın, Z., Energy absorption and exposure buildup factors of essential amino acids, Biomed Research International, 359754, 2014.

[23] Turhan, M.F., Durak, R., Kaçal, M.R., Determination of Gamma Ray Buildup Factors of Some Enzyme Inhibitors, International Journal of Scientific and Engineering Research, 10 (9), 8-13, 2019.

[24] Manohara, S.R., Hanagodimath, S.M., Gerward, L., Energy absorption buildup factors for thermoluminescent dosimetic materials and their tissue equivalent, Radiation Physics and Chemistry, 79, 575-582, 2010.

[25] Kummerer, K., Haiss, A., Schuster, A., Hein, A., Ebert, I., Antineoplastic compounds in the environment-substances of special concern, Environmental Science and Pollution Research, 23(15), 14791-14804, 2016.

[26] Yeo, W., Johnson, P.J., Radiation-recall skin disorders associated with the use of antineoplastic drugs, Pathogenesis, prevalence, and management, American Journal of Clinical Dermatology, 1, 113-116, 2000.

[27] Wiseman, L.R., Adkins J.C., Anastrozole: a review of its use in the management of postmenopausal women with advanced breast cancer, Drugs Aging, 13, 321-32, 1998.

[28] Coukell, A.J., Faulds, D., Epirubicin: An updated review of its pharmacodynamic and pharmacokinetic properties and therapeutic efficacy in the management of breast cancer, Drugs, 53, 453-482, 1997.

[29] Mini, E., Nobili, S., Caciagli, B., Landini, I., Mazzei, T., Cellular pharmacology of gemcitabine, Annals of Oncology, 17, 7-12, 2006. 
[30] Dechant, K.L., Brogden, R.N., Pilkington, T., Faulds, D., Ifosfamide/mesna: A review of its antineoplastic activity, pharmacokinetic properties and therapeutic efficacy in cancer, Drugs 42, 428-467, 1991.

[31] Rowinsky, E.K., Donehower, R.C., Paclitaxel (taxol), The New England Journal of Medicine, 332, $1004-1014,1995$.

[32] Sayyed M.I., Issa S.A., Auda S.H., Assessment of radio-protective properties of some anti-inflammatory drugs, Progress in Nuclear Energy, 100, 297-308, 2017.

[33] Kavaz, E., Ahmadishadbad, N., Özdemir, Y., Photon buildup factors of some chemotherapy drugs, Biomed Pharmacother, 69, 34-41, 2015.

[34] Akman, F., Kaçal, M.R., Investigation of radiation attenuation parameters of some drugs used in Chemotherapy in Wide Energy Region, Journal of Radiology and Oncology, 2, 047$052,2018$.

[35] Ekinci, N., Kavaz, E., Ozdemir, Y., A study of the energy absorption and exposure buildup factors of some anti-inflammatory drugs, Applied Radiation and Isotopes, 90, 265-273, 2014.

[36] Jackson, D.F., Hawkes, D.J., X-ray attenuation coefficients of elements and mixtures, Physics Reports, 70, 169-233, 1981.

[37] Alim, B., Şakar, E., Baltakesmez, A., Han, İ., Sayyed, M.I., Demir, L., Experimental investigation of radiation shielding performances of some important AISI-coded stainless steels: Part I, Radiation Physics and Chemistry, 160, 108455, 2020.

[38] Gerward, L., Guilbert, N.K., Jensen, B., Levring, H., WinXCom-a program for calculating X-ray attenuation coefficients, Radiation Physics and Chemistry, 71(3-4), 653-654, 2004.

[39] Şakar, E., Özpolat, O.F., Alım, B., Sayyed, M.I., Kurudirek, M., Phy-X/PSD: Development of a user friendly online software for calculation of parameters relevant to radiation shielding and dosimetry, Radiation Physics and Chemistry, 108496, 1-12, 2020.

[40] ANSI/ANS-6.4.3, Gamma ray attenuation coefficient and buildup factors for engineering materials, Illinois:American Nuclear Society, La Grange Park, 1991.

[41] Raut, S.D., Awasarmol, V.V., Shaikh, S.F., Ghule, B.G., Ekar, S.U., Mane, R.S., Pawar, P.P., Study of gamma ray energy absorption and exposure buildup factors for ferrites by geometric progression fitting method, Radiation Effects and Defects in Solids, 173 (3-4), 429438, 2018.

[42] Kavaz, E., Perisanoglu, U., Ekinci, N., Ozdemir, Y., Determination of energy absorption and exposure buildup factors by using GP fitting approximation for radioprotective agents, International Journal of Radiation Biology, 92(7); 380-387, 2016. 